\title{
Urethral Stricture is an Unpleasant Complication after Prostate Surgery: A Critical Review of Current Literature
}

\author{
Prostat Cerrahisi Sonrası Can Sıkıcı Komplikasyon Üretral Darlık, Güncel \\ Literatürün Kritik Analizi
}

\author{
Emrullah Söğütdelen, Hakan Bahadır Haberal, Fuad Guliyev, Bülent Akdoğan
}

Hacettepe University Faculty of Medicine, Department of Urology, İstanbul, Turkey

\begin{abstract}
Urethral stricture is narrowing of the urethra due to inflammation that results in scarring. Prostatectomies for benign and malign prostatic diseases are common surgical procedures among men mainly after their fifties. Urethral stricture or bladder neck contraction following transurethral resection of the prostate (TURP) is seen in up to 19\% of men in different series. Urethral stricture after laser prostatectomy is less frequently reported than TURP, which is about 3.6\%. Open prostatectomy for benign prostatic hyperplasia is the oldest technique, nonetheless, it is a reasonable alternative for patients with larger prostates. Urethral stricture is reported in 1.9-4.8\% of patients after open prostatectomy. Radical prostatectomy (RP) is the most common surgical procedure done worldwide for the treatment of localized prostate cancer. Contracture of the bladder neck at the level of the anastomosis is a well-recognized complication after RP occurring in $0.4-32 \%$ of patients. Strictures are mainly treated with endoscopic procedures. Rarely, urethroplasty with buccal mucosa grafts is needed for more complicated cases.

Keywords: Urethral stricture, prostate surgery, transurethral resection, open prostatectomy, radical prostatectomy
\end{abstract}

\section{Öz}

Üretral striktür enflamasyona bağlı olarak skarlaşma sonrası üretradaki daralmadır. Elli yaş üzeri erkeklerde benign ve malign hastalıklara bağlı olarak yapılan prostatektomiler oldukça yaygın olarak uygulanmaktadır. Prostatın transüretral rezeksiyonu sonrası farklı serilerde \%19'a kadar çıkan oranlarda üretral darlık ve mesane boynu kontraksiyonu görülmektedir. Lazer prostatektomi sonrası üretral darlık prostatın transüretral rezeksiyonuna oranla daha az olarak görülmektedir, yaklaşık olarak \%3,6 oranındadır. Açık prostatektomi en eski yöntem olmasına rağmen büyük prostat boyutlu hastalarda oldukça mantıklı bir alternatiftir. Açık prostatektomi sonrası yaklaşık olarak \%1,9-4,8 oranında darlık bildirilmiştir. Radikal prostatektomi (RP) lokalize prostat kanseri tedavisinde bütün dünyada en yaygın olarak uygulanan yöntemdir. RP sonrası anastomoz seviyesinde mesane boynu kontraksiyonu olması iyi bilinen bir komplikasyondur ve yaklaşık olarak hastaların \%0,4-32'sinde görülmektedir. Darlık büyük oranda endoskopik yöntemlerle tedavi edilmektedir, nadiren komplike olgularda bukkal mukoza greftli üretroplasti gerekebilmektedir.

Anahtar Kelimeler: Üretral darlık, prostat cerrahisi, transüretral rezeksiyon, açık prostatektomi, radikal prostatektomi

\section{Introduction}

Prostatectomy is one of the main causes of surgery in aging male population. Besides traditional techniques, novel minimally invasive approaches may also end up with certain complications following prostate surgery. Transurethral procedures may cause iatrogenic urethral trauma. Factors that may influence the development of iatrogenic endoscopic urethral strictures include "electrical dispersion" generated by unipolar current and the "diameter of the instruments" used. Those complications not only bother quality of life of the patients but also may cause various adjunctive procedures with an economical impact.

Urethral stricture is the abnormal narrowing of any segment of the urethra surrounded by corpus spongiosum. It specifically means varying degrees of spongiofibrosis that refers to scarring of the corpus spongiosum (1). Any inflammation of the urethra can result in scarring that can lead to a stricture or a narrowing of the urethra. Besides prostate surgery, trauma, infections, tumors or any other cause of scarring may trigger urethral stricture (2). A recent metaanalysis including 732 patients showed that idiopathic and iatrogenic etiologies were by far the most common, accounting for 33\% and $33 \%$ of all cases, respectively. Inflammatory and posttraumatic etiologies were found in only 15\% and 19\% of patients, respectively (3).

Here, we tried to review the incidence and the basic risk factors that cause urethral stricture following prostate surgery.

\section{Correspondence}

Bülent Akdoğan MD, Hacettepe University Faculty of Medicine, Department of Urology, İstanbul, Turkey

Phone: +90 3123051885 E-mail: blntakdogan@yahoo.com Received: 22.12.2015 Accepted: 22.01.2016 


\section{Stricture after Transurethral Prostate Resection}

Lower urinary tract symptoms (LUTS) secondary to benign prostatic hyperplasia (BPH) are considerably common in aging male population. Despite the development of novel minimally invasive methods, monopolar transurethral resection of the prostate (TURP) remains the gold standard surgical treatment for LUTS related to BPH (4). Annual re-operation rate after TURP is about 1-2\%. A review analyzing 29 randomized controlled trials showed that re-TURP rate was $2.6 \%$ in a mean follow-up of 16 months. Bladder neck contracture and urethral stricture rates were $4.7 \%$ and $3.8 \%$, respectively (5).

Geavlete et al. (6) evaluated long-term complications of monopolar TURP, bipolar TURP and photoselective vaporization of the prostate (PVP) in a prospective, randomized trial. Each study arm had 170 cases. They found that urethral stricture rates were similar in each arm (5.3\%, $6.5 \%, 4.7 \%$, respectively $p=0.768$ ). However, the rate of bladder neck stricture was significantly lower in PVP than in mTURP and bTURP groups $(0.6 \%, 4.1 \%$ and $3.5 \%$, respectively $p=0.047)$. Autorino et al. (7) compared four years results of bTURP vs. MTURP and and found that urethral stricture rates were $3 \%$ vs. $6 \%$, respectively $(p=0.6)$. Sinanoglu et al. (8) compared the long-term outcomes of 85 monopolar TURP (mTURP) and 80 bipolar TUR (bTURP) patients and showed that the stricture rates were, $4.8 \%$ vs. $11.2 \%$, respectively $(p=0.171)$. Stucki et al. (9) prospectively randomized $137 \mathrm{BPH}$ patients to $\operatorname{mTURP}(n=67)$ or bTURP $(n=70)$ arms. There were no significant differences in urethral strictures, however, bladder neck stricture occurred significantly more often in the bipolar group ( $8.5 \%$ vs. $0 \%, p=0.02)$. Komura et al. (10) evaluated the impact of the bipolar TUR system on postoperative urethral stricture rates in a mean follow-up of 36 months. They have detected a significant difference in postoperative urethral stricture rates (6.6\% in mTURP vs. $19.0 \%$ in bTURP $p=0.022$ ). After stratifying patients according to prostate volume, for the patients with a prostate volume of $\leq 70 \mathrm{ml}$, there was no significant difference between the two arms (3.8\% in mTURP vs. $3.8 \%$ in bTUR $p=0.547)$. However, for the patients with larger prostates $(>70 \mathrm{ml})$ significantly higher urethral stricture rates were noted compared to mTURP patients (20\% vs. 2.2\%, respectively $p=0.012$ ). Tang et al. (11) performed a pooled analysis of late complications in more than ten studies. They have showed that bTURP occasionally caused a higher incidence of urethral strictures ( $4 \%$ vs. $3.9 \%$, respectively $p=0.95)$ and bladder neck contractures $(2.7 \%$ vs. $4 \%$, respectively $p=0.08)$ that did not reach a significance.
Basic predisposing factors associated with stricture formation in patients undergoing TURP are increased prostate volume, presence of prostate cancer and the surgeon's experience (12). Mismatch between the size of the instrument and the diameter of the urethral meatus results as meatal strictures, whereas bulbar strictures occur due to insufficient insulation by the lubricant. In order to prevent strictures, lubricant gel must be reapplied when the resection time is getting longer $(13,14)$.

Patients with comorbidities, such as hypertension (HTN), coronary artery disease (CAD) and diabetes mellitus (DM) are also candidates for urethral stricture (8). In patients with comorbidity, bTURP causes higher stricture rates than $\operatorname{mTURP}(p=0.000)(8,15)$.

Recently, new studies showed that TURP inevitably leads to a degree of mechanical urethral stress, the extent of which may depend on the technique used, reflecting the surgeon's skills. Inappropriate axial/rotating movements of the resectoscope and relationship between instrument size and urethral meatus diameter, inadequate lubrication, or longer operating times may lead to urethral stress and stricture (16). Electrothermal trauma is also a specific procedural risk and both in M-TURP and B-TURP and electric current leakage can provoke stenosis $(13,16,17,18)$. Gunes et al. (19) studied the effect of $24 \mathrm{~F}$ versus $26 \mathrm{~F}$ resectoscope size in meatal and bulbar stricture in 71 patients. In terms of meatal stricture, no difference was detected between the groups (5.7\% vs. $4.9 \%$, respectively, $p=0.386)$. However, a significant difference was reported in terms of bulbar stricture formation (2.9\% vs. $11.4 \%$, respectively, $p=0.018)$. In a recent large-scale study, the overall re-treatment rates including reTURP, urethrotomy, and bladder neck incision were 5.8\%, 12.3\%, and $14.7 \%$ at 1,5 , and 8 years, respectively. The incidence of re-TURP was $2.9 \%, 5.8 \%$, and $7.4 \%$ for the same follow-up periods, respectively (Table 1) (20).

\section{Stricture after Laser Prostatectomy}

PVP is a promising technique emerging as a feasible alternative to TURP over the last decades (21). Woo et al. (21) conducted a metaanalysis and reported the incidence of urethral stricture rates in 408 PVP and 353 TURP patients. Both groups had similar urethral stricture rates (3.6\% vs. $6.5 \%$, respectively) (Risk ratio $(R R)=1.77$, $95 \%$ confidence interval=0.94-3.33, $p=0.08$ ). Chung et al. (22) investigated complications related with PVP in 162 anticoagulated

Table 1. Urethral and bladder neck stricture rates in monopolar transurethral resection of the prostate and bipolar transurethral resection of the prostate patients

\begin{tabular}{|c|c|c|c|c|c|c|}
\hline \multirow[t]{2}{*}{ Authors } & \multicolumn{2}{|l|}{ mTURP } & \multicolumn{2}{|l|}{ bTURP } & \multicolumn{2}{|l|}{$p$} \\
\hline & Urethral stricture & $\begin{array}{l}\text { Bladder neck } \\
\text { stricture }\end{array}$ & Urethral stricture & $\begin{array}{l}\text { Bladder neck } \\
\text { stricture }\end{array}$ & Urethral stricture & $\begin{array}{l}\text { Bladder neck } \\
\text { stricture }\end{array}$ \\
\hline Sinanoglu et al. (8) & $3 / 85(4 \%)$ & - & $8 / 80$ (10\%) & - & 0.102 & - \\
\hline Stucki et al. (9) & $1 / 67(1.5 \%)$ & 0/67 (0\%) & $1 / 70(1.4 \%)$ & $6 / 70$ (8.5\%) & 1 & 0.02 \\
\hline Autorino et al. (7) & $2 / 31(6 \%)$ & $1 / 32(3 \%)$ & $1 / 31(3 \%)$ & $1 / 32(3 \%)$ & 0.6 & 0.8 \\
\hline Geavlete et al. (6) & $9 / 170(5.1 \%)$ & $7 / 170(4.1 \%)$ & $11 / 170(6.3 \%)$ & $6 / 170(3.4 \%)$ & 0.768 & 0.047 \\
\hline Komura et al. (10) & $4 / 61(6 \%)$ & - & $12 / 63(19 \%)$ & - & 0.022 & - \\
\hline Tang et al. (11) & $36 / 909$ (3.9\%) & $37 / 852$ (4\%) & $38 / 948$ (4\%) & $25 / 899(2.7 \%)$ & 0.95 & 0.008 \\
\hline Mamoulakis et al. (16) & 10/108 (9.3\%) & $2 / 108$ (1.9\%) & $10 / 122(8.2 \%)$ & $8 / 122(6.6 \%)$ & 0.768 & 0.02 \\
\hline
\end{tabular}


patients and no urethral stricture was reported. Batura et al. (23) studied the complications of PVP-120 W high performance system (GreenLight ${ }^{\text {TM }}$ lithium triborate laser). According to study it has been showed that the rate of urethral strictures $(4 / 117,3.4 \%)$ was low and comparable with TURP in a mean follow-up of 20 months.

Holmium laser enucleation of the prostate (HoLEP) has emerged as an effective transurethral treatment option in patients with symptomatic BPH of any size (24). Krambeck et al. (25) reported results of 1065 holmium laser prostate enucleations. Urethral stricture was noted in $9(0.9 \%), 11(1.3 \%), 4(1.3 \%)$ and 0 patients, and bladder neck contracture was found in $0,7(0.8 \%), 4(1.3 \%)$ and $5(6.0 \%)$ patients at short, intermediate, long-term and more than 5-years of follow-up, respectively. Elzayat and Elhilali (26) retrospectively analyzed urethral strictures in 225 patients with a median prostate volume of 126 grams. In a mean follow-up of 31 months, strictures occurred in 3 patients (1.3\%), meatal stenosis in 1 patient and bladder neck contracture was noted in 1 patient (0.4\%). Elmansy et al. (27) conducted a retrospective analysis of 949 patients treated with HoLEP. Bladder neck contracture and urethral strictures developed in $0.8 \%$ and $1.6 \%$ of patients, respectively, in 62 months of follow-up (27). HoLEP is now considered as new gold standard treatment for symptomatic BPH (Table 2, 3).

\section{Stricture after Open Prostatectomy}

At the beginning of the $20^{\text {th }}$ century, open prostatectomy was accepted as the reference standard treatment option for BPH (28). Although open prostatectomy is the oldest technique, it is most frequently preferred option for patients with large prostates (>80 cc) (29). Open prostatectomy is not performed only in technologically underdeveloped areas of the world. Studies from several European countries, such as Sweden and France, have shown that this procedure is performed for $12-14 \%$ of prostatectomies $(30,31)$.

Varkarakis et al. (32) reported long-term complications of open prostatectomy in 232 patients with prostates $>75$ grams. In a mean follow-up of 41.8 months, the rates of bladder neck contractions, urethral strictures and meatal stenosis were 3.3\%, 0.6\% and 1.3\%, respectively. Another study from Turkey included 664 patients and it was shown that the rate of late complications, such as bladder neck stenosis and meatal stenosis occurred in 3.2\% and 2.3\% of patients, respectively (33). The Sicilian-Calabrian Society of Urology performed a retrospective study to assess the surgical management of $\mathrm{BPH}$. Open prostatectomy accounted for $32 \%(1.804 / 31.558)$ of all surgical treatment alternatives (34). In that study, the most frequent late complications were urethral and/or bladder neck stenosis $87 / 1804$ (4.8\%) (34).

In underdeveloped countries, the selection of this approach is usually compulsory and dictated by the lack of transurethral instruments and endourological expertise (Table 4) (32).

\section{Stricture after Radical Prostatectomy}

Radical prostatectomy (RP) is the most common procedure worldwide to treat localized prostate cancer. Due to widespread use of prostate-specific antigen (PSA) testing, patients operated today are often younger and have organ-confined disease, justifying a more preservative surgery (35). Contracture of the bladder neck at the level of the anastomosis between the bladder and the membranous urethra is a well-recognized complication after RP, reportedly occurring in $0.4-32 \%$ of patients $(36,37,38,39)$. The risk of vesicourethral anastomosis stricture (VUAS) has decreased by time with improved surgical techniques (35).

Wang et al. (40) evaluated the difference between the rates of vesicourethral anastomotic stenosis after open RP $(n=707)$ and robotassisted radical prostatectomy (RARP) $(n=1038)$ and analyzed associated factors and the effect of stenosis on quality of life. The incidence of VUAS was higher in open RP than in RARP (7.5\% vs. 2.1\%, respectively, $\mathrm{p}<0.01)$. Open technique odds ratio (OR) (OR 3.0), PSA recurrence (OR 2.2), postoperative hematuria (OR 3.7), urinary leak (OR 6.0), and urinary retention (OR 3.5) were significant independent predictors of VUAS development (40). Sandhu et al. (41) studied predictors of symptomatic anastomotic strictures in 3.458 open RP (75\%) and 1.134 laparoscopic RP (25\%). The laparoscopic RP group included 97 robotic-assisted cases. Symptomatic anastomotic strictures developed in 198 patients (4.3\%). On multivariate analysis, significant predictors included patient age (OR 1.03), body mass index (OR 1.04), Charlson score (OR 1.3), renal insufficiency (OR 4), individual surgeon experience (OR 0.08-9.7), and the presence of postoperative urinary leak (OR 2.3) or hematoma (OR 2.8). Borboroglu et al. (42) hypothesized that the presence of microvascular disease may lead to impaired healing and results in stricture. In their series including 467 patients treated with $\mathrm{RP}$, vesicourethral stricture occurred in $11.1 \%$ of subjects. Recognized factors leading to microvascular disease, such as current cigarette smoking resulted in a significantly higher (26\%) rate of VUAS $(p<0.001)$. The VUAS rate was also increased in patients with CAD $(26 \%, p<0.001)$, HTN $(19 \%, p=0.015)$, and DM $(21 \%, p=0.030)$. The mean surgery time was longer ( $271 \mathrm{vs.} 249$ minutes, $p=0.025$ ) and the estimated blood loss was greater (1639 vs. $1092 \mathrm{ml}, \mathrm{p}<0.001$ ) in patients developing a VUAS.

Table 2. Comparison between photoselective vaporization of the prostate and transurethral resection of the prostate in terms of urethral and bladder neck stricture

\begin{tabular}{|l|l|l|l|l|l|l|}
\hline Authors & \multicolumn{2}{l|}{ PVP } & TURP & \multicolumn{2}{l|}{ p } \\
\hline & Urethral stricture & $\begin{array}{l}\text { Bladder neck } \\
\text { stricture }\end{array}$ & Urethral stricture & $\begin{array}{l}\text { Bladder neck } \\
\text { stricture }\end{array}$ & Urethral stricture & $\begin{array}{l}\text { Bladder neck } \\
\text { stricture }\end{array}$ \\
\hline Woo et al. (21) & $15 / 408(3.6 \%)$ & - & $23 / 353(6.5 \%)$ & - & 0.08 & - \\
\hline Chung et al. (22) & $0 / 162(0 \%)$ & $0 / 162(0 \%)$ & - & - & - & - \\
\hline Batura et al. (23) & $4 / 117(3.4 \%)$ & - & - & - & - & - \\
\hline PVP: Photoselective vaporization of the prostate, TURP: Transurethral resection of the prostate & \\
\hline
\end{tabular}


Table 3. Urethral-meatal stricture and bladder neck stricture after Holmium laser enucleation of the prostate

\begin{tabular}{|l|l|l|}
\hline Authors & HoLEP \\
\hline & $\begin{array}{l}\text { Urethral-meatal } \\
\text { stricture }\end{array}$ & $\begin{array}{l}\text { Bladder neck } \\
\text { stricture }\end{array}$ \\
\hline Elmansy et al. (27) & $15 / 949(1.6 \%)$ & $7 / 949(0.8 \%)$ \\
\hline Elzayat and Elhilali (26) & $4 / 225(1.7 \%)$ & $1 / 225(0.4 \%)$ \\
\hline Krambeck et al. (25) & $24 / 1065(0.02 \%)$ & $16 / 1065(0.01 \%)$ \\
\hline \multicolumn{2}{|l|}{ HoLEP: Holmium laser enucleation of the prostate } \\
\hline
\end{tabular}

Table 4. Urethral-meatal stricture and bladder neck stricture after open prostatectomy

\begin{tabular}{|l|l|l|}
\hline Authors & \multicolumn{3}{|l|}{ Open prostatectomy } \\
\hline & $\begin{array}{l}\text { Urethral-meatal } \\
\text { stricture }\end{array}$ & $\begin{array}{l}\text { Bladder neck } \\
\text { stricture }\end{array}$ \\
\hline Varkarakis et al. (32) & $3 / 232(1.9 \%)$ & $5 / 232(3.3 \%)$ \\
\hline Suer et al. (33) & $15 / 664(2.3 \%)$ & $22 / 664(3.2)$ \\
\hline Serratta et al. (34) & $87 / 1804(4.8 \%)$ & \\
\hline
\end{tabular}

The majority of comparative studies report low and overlapping rates of anastomotic stricture in open RP (mean: $7.2 \%$; range: 1.816\%) and laparoscopic RP (mean: 3.0\%; range: 0-6.4\%). However, cumulative meta-analysis data reveals that strictures are significantly less common in laparoscopic RP $(R R=2.92)(43,44,45,46,47)$.

Anastomotic tension, urinary extravasation, poor tissue handling and ischemia are the main proposed mechanisms for BNC after RP. Intraoperative and postoperative factors, such as excessive blood loss, type of bladder neck dissection, postoperative urinary leakage, adjuvant radiotherapy, previous TURP, current cigarette smoking, older age, obesity, surgeon experience, open vs. minimally invasive surgery, and acute postoperative retention treated with suprapubic tube placement also influence the VUAS rates $(38,48,49,50,51,52)$.

\section{Management of Urethral Stricture}

\section{Urethral Dilation}

There are several methods for urethral dilation, such as dilation with a balloon, filiform and followers, urethral sounds or self-dilatation with catheters. Steenkamp et al. (53) showed that urethral dilatation and optical internal urethrotomy under local anaesthesia are equally successful as initial outpatient treatment. With regard to successful performance of the procedure itself, multiple, longer $(>2 \mathrm{~cm})$, posttraumatic, and previously untreated strictures are better managed with dilatation, whereas patients with complications or retention are better managed with internal urethrotomy.

\section{Internal Urethrotomy}

Direct vision internal urethrotomy (DVIU) is performed by using a coldknife transurethral incision to release scar tissue, allowing the tissue to heal by secondarily at a larger caliber and thereby increasing the size of the urethral lumen. In different recent studies shows that overall long-term success rates are estimated to be just $20-30 \%(54,55)$. Recurrence is more likely influenced by length of stricture; the risk of recurrence at 12 months is $40 \%$ for strictures shorter than $2 \mathrm{~cm}, 50 \%$ for strictures between 2-4 cm, and 80\% for strictures longer than 4 cm (56). Recurrence rates also vary according to stricture location; $58 \%$ of bulbar strictures will recur after urethrotomy, compared with $84 \%$ for penile strictures and 89\% for membranous strictures (55).

According to recent studies, the efficacy of agents such as mitomycin $\mathrm{C}$ and triamcinolone injected into the scar tissue has been studied to decrease recurrence rates at the time of internal urethrotomy $(57,58,59,60,61)$.

Laser urethrotomies are another method to manage the anterior urethral stricture with a reported success rate of $20-80 \%$ in different studies $(62,63)$.

\section{Urethroplasty}

Several techniques have been used for urethroplasty, including excision and primary reanastomosis, onlay grafting and the use of flaps. Long-term success rates are much higher for urethroplasty (8590\%) than for urethrotomy (20-30\%) (64).

In fact, urethroplasty is the most effective method for definitive correction of urethral strictures and this is generally considered to be the gold-standard treatment $(61,65,66)$. Risk factors associated with failure include incomplete excision of scar tissue, anastomotic tension and the presence of lichen sclerosis (67).

The basic principle in treatment of urethral stricture is that internal urethrotomy promises an acceptable success rate only in short-term and first-time strictures. In a recurrent stricture, open reconstruction is technique of choice then repeated urethrotomies. It is very important that open reconstructive surgery should be carried out at experienced centers to achieve the best results (68).

\section{Conclusion}

Urethral stricture is an unpleasant complication after prostate surgery. In different studies, the incidence of urethral stricture, bladder neck contracture or VUAS has been reported to be less than $5 \%$ after endoscopic or open procedures. Urethral stricture management modalities can achieve a success rate of $20-90 \%$ in adequate experienced centers. Primary DVIU/dilation is indicated as the firstline therapy for short $(<1-2 \mathrm{~cm})$, single, bulbar urethral strictures. $A$ second DVIU/dilation can be indicated for recurrent urethral strictures with favorable characteristics ( $<1-2 \mathrm{~cm}$, single, bulbar stricture) with recurrence $>3$ months after previous treatment. A third DVIU/dilation is not recommended, except if necessitated by patient comorbidities or economic resources. Urethral reconstructions over repeat DVIU/ dilation should be offered for urethral strictures that recur within 6 months or are refractory to a second DVIU/dilation. Surgeons should be aware of this unpleasant complication and be cautious to prevent it just before the prostate surgery.

\section{Ethics}

Peer-review: Internal peer-reviewed.

\section{Authorship Contributions}

Concept: Emrullah Söğütdelen, Hakan Bahadır Haberal, Bülent Akdoğan, Fuad Guliyev, Design: Emrullah Söğütdelen, Hakan Bahadır Haberal, Bülent Akdoğan, Fuad Guliyev, Data Collection or Processing: Emrullah Söğütdelen, Hakan Bahadır Haberal, Bülent Akdoğan, Fuad Guliyev, Analysis or Interpretation: Emrullah Söğütdelen, Hakan Bahadır Haberal, Bülent Akdoğan, Fuad Guliyev, Literature 
Search: Emrullah Söğütdelen, Hakan Bahadır Haberal, Bülent Akdoğan, Fuad Guliyev, Writing: Emrullah Söğütdelen, Hakan Bahadır Haberal, Bülent Akdoğan, Fuad Guliyev. Conflict of Interest: No conflict of interest was declared by the authors, Financial Disclosure: The authors declared that this study has received no financial support.

\section{References}

1. No authors listed. Proceedings of International Consultation on Urologic Diseases: Urethral Strictures, International Consultation on Urethral Strictures, in conjunction with the Société Internationale d'Urologie (SIU) World Meeting, 13-16 October 2010, Marrakech, Morocco. Urology 2014;83(Suppl 3):1-73.

2. Latini JM, Mcaninch JW, Brandes SB, Chung JY, Rosenstein D. Consultation on urethral strictures: epidemiology, etiology, anatomy, and nomenclature of urethral stenoses, strictures, and pelvic fracture urethral disruption injuries. Urology 2014;83(3 Suppl):S1-7.

3. Fenton AS, Morey AF, Aviles R, Garcia CR. Anterior urethral strictures: Etiology and characteristics. Urology 2005;65:1055-1058.

4. Madersbacher S, Alivizatos G, Nordling J, Sanz CR, Emberton M, de la Rosette JJ. Eau 2004 guidelines on assessment, therapy and follow-up of men with lower urinary tract symptoms suggestive of benign prostatic obstruction (bph guidelines). Eur Urol 2004;46:547-554.

5. Madersbacher $S$, Marberger M. Is transurethral resection of the prostate still justified? BJU Int 1999;83:227-237.

6. Geavlete B, Georgescu D, Multescu R, Stanescu F, Jecu M, Geavlete P. Bipolar plasma vaporization vs monopolar and bipolar turp-a prospective, randomized, long-term comparison. Urology 2011;78:930-935.

7. Autorino R, Damiano R, Di Lorenzo G, Quarto G, Perdonà S, D'Armiento $M$, De Sio M. Four-year outcome of a prospective randomised trial comparing bipolar plasmakinetic and monopolar transurethral resection of the prostate. Eur Urol 2009;55:922-929.

8. Sinanoglu O, Ekici S, Tatar MN, Turan G, Keles A, Erdem Z. Postoperative outcomes of plasmakinetic transurethral resection of the prostate compared to monopolar transurethral resection of the prostate in patients with comorbidities. Urology 2012;80:402-406.

9. Stucki P, Marini L, Mattei A, Xafis K, Boldini M, Danuser H. Bipolar versus monopolar transurethral resection of the prostate: a prospective randomized trial focusing on bleeding complications. J Urol 2015;193:1371-1375.

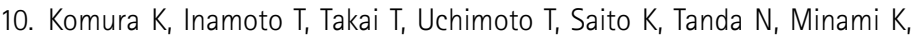
Oide R, Uehara H, Takahara K, Hirano H, Nomi H, Kiyama S, Watsuji T, Azuma $H$. Incidence of urethral stricture after bipolar transurethral resection of the prostate using turis: results from a randomised trial. BJU Int 2015;115:644-652.

11. Tang Y, Li J, Pu C, Bai Y, Yuan H, Wei Q, Han P. Bipolar transurethral resection versus monopolar transurethral resection for benign prostatic hypertrophy: a systematic review and meta-analysis. I Endourol 2014;28:1107-1114.

12. Hammarsten J, Lindqvist $K$, Sunzel $H$. Urethral strictures following transurethral resection of the prostate. the role of the catheter. $\mathrm{Br} J$ Urol 1989;63:397-400.

13. Rassweiler J, Teber D, Kuntz R, Hofmann R. Complications of transurethral resection of the prostate (turp)--incidence, management, and prevention. Eur Urol 2006;50:969-979.

14. Summerton DJ, Kitrey ND, Lumen N, Serafetinidis E, Djakovic N. EAU guidelines on iatrogenic trauma. Eur Urol 2012;62:628-639.

15. Sinanoglu O, Ekici S, Balci MC, Hazar Al, Nuhoglu B. Comparison of plasmakinetic transurethral resection of the prostate with monopolar transurethral resection of the prostate in terms of urethral stricture rates in patients with comorbidities. Prostate Int 2014;2:121-126.
16. Mamoulakis C, Schulze M, Skolarikos A, Alivizatos G, Scarpa RM, Rassweiler JJ, de la Rosette JJ, Scoffone CM. Midterm results from an international multicentre randomised controlled trial comparing bipolar with monopolar transurethral resection of the prostate. Eur Urol 2013;63:667-676.

17. Faul P, Schlenker B, Gratzke C, Stief CG, Reich O, Hahn RG. Clinical and technical aspects of bipolar transurethral prostate resection. Scand J Urol Nephrol 2008;42:318-323.

18. Michielsen DP, Coomans D. Urethral strictures and bipolar transurethral resection in saline of the prostate: fact or fiction? J Endourol 2010;24:1333-1337.

19. Gunes $M$, Keles MO, Kaya C, Koca O, Sertkaya Z, Akyüz M, Altok M, Umul $\mathrm{M}$, Karaman MI. Does resectoscope size play a role in formation of urethral stricture following transurethral prostate resection? Int Braz J Urol 2015;41:744-749.

20. Madersbacher S, Lackner J, Brossner $C$, Röhlich M, Stancik I, Willinger M, Schatzl G; Prostate study group of the austrian society of urology. reoperation, myocardial infarction and mortality after transurethral and open prostatectomy: a nation-wide, long-term analysis of 23,123 cases. Eur Urol 2005;47:499-504.

21. Woo H, Thangasamy I, Chalasani V. Photoselective vaporization with the green light laser vs transurethral resection of the prostate for treating benign prostate hyperplasia: a systematic review and meta-analysis. BJU Int 2013;111:E137.

22. Chung DE, Wysock JS, Lee RK, Melamed SR, Kaplan SA, Te AE. Outcomes and complications after $532 \mathrm{~nm}$ laser prostatectomy in anticoagulated patients with benign prostatic hyperplasia. J Urol 2011;186:977-981.

23. Batura D, Sahibzada I, Elkabir J, Feyisetan O, Izegbu V, Hellawell G, Webster J. Durability and complications of photoselective vaporisation of the prostate with the 120w high performance system greenlight lithium triborate laser. Ann R Coll Surg Engl 2014;96:359-363.

24. Tooher $R$, Sutherland $P$, Costello A, Gilling P, Rees G, Maddern G. A systematic review of holmium laser prostatectomy for benign prostatic hyperplasia. J Urol 2004;171:1773-1781.

25. Krambeck $A E$, Handa $S E$, Lingeman JE. Experience with more than 1,000 holmium laser prostate enucleations for benign prostatic hyperplasia. J Urol 2013;189(1 Suppl):S141-145.

26. Elzayat $E A$, Elhilali MM. Holmium laser enucleation of the prostate (holep): The endourologic alternative to open prostatectomy. Eur Urol 2006;49:87-91.

27. Elmansy HM, Kotb $A$, Elhilali MM. Holmium laser enucleation of the prostate: long-term durability of clinical outcomes and complication rates during 10 years of followup. J Urol 2011;186:1972-1976.

28. Freyer PJ. A recent series of 60 cases of total enucleation of the prostate for radical cure of enlargement of that organ. Br Med J 1905;1:1085-1089.

29. Mcnicholas TA. Management of symptomatic BPH in the UK: Who is treated and how? Eur Urol 1999;36 Suppl 3:33-39.

30. Ahlstrand $C_{1}$ Carlsson $P_{1}$ Jonsson B. An estimate of the life-time cost of surgical treatment of patients with benign prostatic hyperplasia in sweden. Scand J Urol Nephrol 1996;30:37-43.

31. Lukacs B. Management of symptomatic bph in france: Who is treated and how? Eur Urol 1999;36 Suppl 3:14-20.

32. Varkarakis I, Kyriakakis Z, Delis A, Protogerou V, Deliveliotis C. Long-term results of open transvesical prostatectomy from a contemporary series of patients. Urology 2004;64:306-310.

33. Suer E, Gokce I, Yaman 0, Anafarta K, Göğüş 0. Open prostatectomy is still a valid option for large prostates: a high-volume, single-center experience. Urology 2008;72:90-94.

34. Serretta V, Morgia G, Fondacaro L, Curto G, Lo Bianco A, Pirritano D, Melloni $D$, Orestano $F$, Motta $M$, Pavone-Macaluso M; Members of the siciliancalabrian society of urology. open prostatectomy for benign prostatic enlargement in southern europe in the late 1990s: a contemporary series of 1800 interventions. Urology 2002;60:623-627. 
35. Hugosson J, Stranne J, Carlsson SV. Radical retropubic prostatectomy: a review of outcomes and side-effects. Acta Oncol 2011;50 Suppl 1:92-97.

36. Dalkin BI. Endoscopic evaluation and treatment of anastomotic strictures after radical retropubic prostatectomy. J Urol 1996;155:206-208.

37. Shimizu T, Takahashi A, Ichihara K, Shinkai N, Ikeda T, Nojima M, Takagi Y. [Anastomotic stricture following radical retropubic prostatectomy: insights into incidence, management and factors predisposing for occurrence]. Nihon Hinyokika Gakkai Zasshi 2012;103:604-609.

38. Surya Bv, Provet J, Johanson Ke, Brown J. Anastomotic strictures following radical prostatectomy: risk factors and management. J Urol 1990;143:755-758.

39. Tomschi W, Suster G, Holtl W. Bladder neck strictures after radical retropubic prostatectomy: still an unsolved problem. $\mathrm{Br} J$ Urol 1998;81:823-826.

40. Wang R, Wood DP Jr., Hollenbeck Bk, Li AY, He C, Montie JE, Latini JM. Risk factors and quality of life for post-prostatectomy vesicourethral anastomotic stenoses. Urology 2012;79:449-457.

41. Sandhu JS, Gotto GT, Herran LA, Scardino PT, Eastham JA, Rabbani F. Age, obesity, medical comorbidities and surgical technique are predictive of symptomatic anastomotic strictures after contemporary radical prostatectomy. J Urol 2011;185:2148-2152.

42. Borboroglu PG, Sands JP, Roberts JL, Amling CL. Risk factors for vesicourethral anastomotic stricture after radical prostatectomy. Urology 2000;56:96-100.

43. Poulakis V, Witzsch U, de Vries R, Dillenburg W, Becht E. Laparoscopic radical prostatectomy in men older than 70 years of age with localized prostate cancer: comparison of morbidity, reconvalescence, and shortterm clinical outcomes between younger and older men. Eur Urol 2007:51:1341-1348; discussion 1349.

44. Rassweiler J, Seemann O, Schulze M, Teber D, Hatzinger M, Frede T. Laparoscopic versus open radical prostatectomy: A comparative study at a single institution. J Urol 2003;169:1689-1693.

45. Remzi M, Klingler HC, Tinzl MV, Fong YK, Lodde $M$, Kiss B, Marberger M. Morbidity of laparoscopic extraperitoneal versus transperitoneal radical prostatectomy verus open retropubic radical prostatectomy. Eur Urol 2005;48:83-89; discussion 89.

46. Roumeguere $T$, Bollens $R$, Vanden Bossche $M$, Rochet $D$, Bialek $D_{1}$ Hoffman P, Quackels T, Damoun A, Wespes E, Schulman CC, Zlotta AR. Radical prostatectomy: a prospective comparison of oncological and functional results between open and laparoscopic approaches. World J Urol 2003;20:360-366.

47. Touijer K, Eastham JA, Secin FP, Romero Otero J, Serio A, Stasi J, SanchezSalas R, Vickers A, Reuter VE, Scardino PT, Guillonneau B. Comprehensive prospective comparative analysis of outcomes between open and laparoscopic radical prostatectomy conducted in 2003 to 2005. J Urol 2008;179:1811-1817.

48. Hu JC, Gu X, Lipsitz SR, Barry MJ, D'Amico AV, Weinberg AC, Keating NL. Comparative effectiveness of minimally invasive vs open radical prostatectomy. JAMA 2009;302:1557-1564.

49. Levy JB, Ramchandani P, Berlin JW, Broderick GA, Wein AJ. Vesicourethral healing following radical prostatectomy: Is it related to surgical approach? Urology 1994;44:888-892.
50. Rabbani $F$, Yunis Lh, Pinochet $R$, Nogueira $L$, Vora KC, Eastham JA, Guillonneau B, Laudone V, Scardino PT, Touijer K. Comprehensive standardized report of complications of retropubic and laparoscopic radical prostatectomy. Eur Urol 2010;57:371-386.

51. Srougi M, Paranhos M, Leite KM, Dall'Oglio M, Nesrallah L. The influence of bladder neck mucosal eversion and early urinary extravasation on patient outcome after radical retropubic prostatectomy: a prospective controlled trial. BJU Int 2005;95:757-760.

52. Thiel DD, Igel TC, Brisson TE, Heckman MG. Outcomes with an alternative anastomotic technique after radical retropubic prostatectomy: 10-year experience. Urology 2006;68:132-136.

53. Steenkamp JW, Heyns CF, de Kock ML. Outpatient treatment for male urethral strictures--dilatation versus internal urethrotomy. S Afr J Surg 1997;35:125-130.

54. Dubey D. The current role of direct vision internal urethrotomy and selfcatheterization for anterior urethral strictures. Indian J Urol 2011;27:392396.

55. Pansadoro $V$, Emiliozzi P. Internal urethrotomy in the management of anterior urethral strictures: long-term follow up. J Urol 1996;156:73-75.

56. Steenkamp JW, Heyns CF, De Kock ML. Internal urethrotomy versus dilation as treatment for male urethral strictures: a prospective, randomized comparison. J Urol 1997;157:98-101.

57. Mazdak $H$, Izadpanahi $M H_{1}$ Ghalamkari $A$, Kabiri $M$, Khorrami $\mathbf{M H}$, Nouri-Mahdavi K, Alizadeh F, Zargham M, Tadayyon F, Mohammadi A, Yazdani M. Internal urethrotomy and intraurethral submucosal injection of triamcinolone in short bulbar urethral strictures. Int Urol Nephrol 2010;42:565-568.

58. Mazdak H, Meshki I, Ghassami F. Effect of mitomycin c on anterior urethral stricture recurrence after internal urethrotomy. Eur Urol 2007:51:10891092.

59. Tavakkoli Tabassi K, Yarmohamadi A, Mohammadi S. Triamcinolone injection following internal urethrotomy for treatment of urethral stricture. Urol J 2011;8:132-136.

60. Vanni AJ, Zinman LN, Buckley JC. Radial urethrotomy and intralesional mitomycin c for the management of recurrent bladder neck contractures. J Urol 2011:186:156-160.

61. Hampson LA, McAninch JW, Breyer BN. Male urethral strictures and their management. Nat Rev Urol 2014;11:43-50.

62. Turek PJ, Malloy TR, Cendron M, Carpiniello VL, Wein AJ. Ktp-532 laser ablation of urethral strictures. Urology 1992;40:330-334.

63. Bloiso G, Warner R, Cohen M. Treatment of urethral diseases with neodymium: Yag laser. Urology 1988;32:106-110.

64. Wong SS, Aboumarzouk OM, Narahari R, O'Riordan A, Pickard R. Simple urethral dilatation, endoscopic urethrotomy, and urethroplasty for urethral stricture disease in adult men. Cochrane Database Syst Rev 2012;12:CD006934.

65. Wong SS, Narahari R, O'Riordan A, Pickard R. Simple urethral dilatation, endoscopic urethrotomy, and urethroplasty for urethral stricture disease in adult men. Cochrane Database Syst Rev 2010;4:CD006934.

66. Mundy AR, Andrich DE. Urethral strictures. BJU Int 2011;107:6-26.

67. Koraitim MM. Failed posterior urethroplasty: Lessons learned. Urology 2003;62:719-722. 